\title{
COUNTDOWN TO 2010: CAN WE ASSESS IRELAND'S INSECT SPECIES DIVERSITY AND LOSS?
}

\author{
Eugenie Regan, Brian Nelson, Stephen McCormack, Robert Nash \\ and James P. O’Connor
}

\begin{abstract}
The insects are the most diverse organisms on this planet and play an essential role in ecosystem functioning, yet we know very little about them. In light of the Convention on Biological Diversity, this paper summarises the known insect species numbers for Ireland and questions whether this is a true reflection of our insect diversity. The total number of known species for Ireland is 11,422. Using species accumulation curves and a comparison with the British fauna, this study shows that the Irish list is incomplete and that the actual species number is much higher. However, even with a reasonable knowledge of the species in Ireland, insects are such speciose, small, and inconspicuous animals that it is difficult to assess species loss. It is impossible to know at one point in time the number of insect species in Ireland and, although it is useful to summarise the known number of species, it is essential that biodiversity indicators, such as the Red List Index, are developed.
\end{abstract}

Eugenie Regan (corresponding author; email: eugenie.regan@ gmail.com), School of Natural Sciences, Trinity College Dublin, Dublin 2 and National Biodiversity Data Centre, WIT

West Campus, Waterford; Brian Nelson and Robert Nash, Department of Natural Sciences, National Museums Northern Ireland, Cultra, Holywood, Co. Down, BT18 OEU; Stephen McCormack, Johnstown Research Centre, Teagasc, Johnstown, Co. Wexford; and James P. O'Connor, National Museum of Ireland, Kildare Street,

Dublin 2.

Received 29 September 2009.

Accepted 18

February 2010.

Published 3

September 2010.

\section{INTRODUCTION}

Information on Ireland's insect species diversity has been difficult to access because the information has been widely scattered. Previous attempts to quantify the species richness of Irish insects (e.g. Speight 1986; Purcell 1996) relied substantially on estimates for some groups. Over the last decade, however, there has been a steady production of modern Irish checklists and updated catalogues covering virtually all the Irish insect fauna (notably Anderson et al. 1997; Bond et al. 2006; Chandler et al. 2008; O'Connor 2008; O'Connor et al. 2009). The recent flow of published, validated checklists has made a more accurate summary of the insects resident in Ireland possible.

This paper summarises information on Ireland's insect species diversity and presents an overview of the total number of known species in Ireland. It also assesses whether our knowledge of the insect diversity is comprehensive and complete and discusses the issues of extinction and conservation in this fauna.

This work is timely given the context of the Convention on Biological Diversity, the signatories of which committed themselves to achieve a significant reduction in the current rate of biodiversity loss at a global, regional and national level by 2010 (United Nations 1992). In 2001 all the European Union states, including Ireland and the United Kingdom, set a more ambitious target to halt biodiversity loss by 2010 (European Commission 2006). However, there are many gaps in our knowledge of the biodiversity on the island of Ireland, in particular the numbers of species that occur here and the rate of biodiversity loss (DAHGI 2002; EPA 2008). Without this information, it is impossible to assess whether this commitment will have been achieved. The National Biodiversity Plan (DAHGI 2002) further acknowledges this, stating that basic inventories on all species groups are fundamental to the conservation of biodiversity.

Insects are the most species-rich group of animals on earth, constituting over $60 \%$ of the 1.5 million described species (Baillie et al. 2004). Estimates of the total number of species vary widely, from a few million to more than 30 million, largely due to the uncertainty in the global biodiversity of insects (May 1990). In Ireland's case previous estimates for the total number of animal species (terrestrial and marine) range from 14,616 (Purcell 1996) to c. 21,000 (Good 2009), of which insects contributed 7162 (49\%) and c. $13,000(62 \%)$ respectively (the latter figure (Good 2009) is acknowledged as likely to be an underestimate, particularly with respect to nematoceran flies and parasitoid wasps). O'Connor (1997) estimated that there are around 16,000 insect species in Ireland. Recently, Ferriss et al. (2008) summarised Ireland's known fauna 
and found published references for 19,122 animal species, of which 11,260 (59\%) were insects (Regan and McCormack 2009). It is reasonable to assume that the majority of species in Ireland are also insects, and the value of this statistic has to be determined in order to measure the progress toward of the 2010 target.

\section{METHODOLOGY}

The information presented here is based on a number of recently published checklists and review papers or catalogues and expert input. The Hemiptera is the only large group of insects for which there is no modern list and the species number for this group has been compiled with the assistance of relevant experts. Additional species recorded as new to Ireland subsequent to the cited lists have generally not been included. Where it is known to us or explicitly stated in the checklist, we have excluded species that have only been recorded from artificial situations (such as greenhouses) or as vagrants. The original checklists should be consulted to confirm the status of all species. Checklists of Irish insects have been produced since the middle of the nineteenth century (Nash 1983; Beirne 1985). These have always covered the entire island of Ireland (i.e. the political entities of Northern Ireland and the Republic Ireland) and we follow that convention here, with the term Ireland referring to the whole island. Nomenclature follows the checklist, catalogue, review or list cited. It should be borne in mind that checklists represent the state of knowledge at a point in time. They may vary in their completeness, accuracy and inclusion of non-native species.

\section{RESULTS AND DISCUSSION}

KNOWN NUMBER OF SPECIES IN IRELAND

A total of 11,422 species in 21 orders have been recorded from Ireland (Table 1). The largest orders (with more than 1000 recorded species) are the Diptera, Hymenoptera, Coleoptera and Lepidoptera with 3313, 3194, 2154 and 1454 species recorded, respectively. These four orders account for $89 \%$ of the total insect fauna (Fig. 1), with the next most species-rich order being the Hemiptera, with 770 species. These five orders stand out for their high species richness in the world fauna as well (Table 2). However, the predominance of the Diptera and Hymenoptera in the Irish fauna does not replicate the pattern of global biodiversity, where the two most species rich taxa globally appear to be the Coleoptera and Lepidoptera (Table 2). It may be argued that the Irish insect fauna is relatively well known as compared to the world insect fauna. Finlay et al. (2006) showed self-similar patterns of species richness for insect families across six different regions, including the UK, Australia and the world. The dominance of beetles in the world fauna may be an artefact of the collection and research biases of entomologists, and studies of canopy insects of the tropical island of Borneo have shown that Hymenoptera and Diptera can outnumber Coleoptera at particular sites (Gullan and Cranston 2004).

\section{COMPLETE LISTS?}

The figures presented in Table 1 summarise the current state of knowledge for insect species richness in Ireland. However, is this an accurate reflection of the actual species numbers for Ireland? Are there more species than is currently known? Are the species that have been recorded still extant? Or were they ever established?

Almost one-third (29\%) of the entire insect fauna is composed of Diptera. Out of the total of 3313 recorded species, 442 of these were added to the Irish list in the last ten years (Chandler et al. 2008), an increase of $15 \%$. The families with the largest additions were the Sciaridae, Chironomidae, Anthomyiidae, and the Chloropidae, all of which are small flies that can be taxonomically difficult to identify and with few taxonomists working on them. There are several other groups of taxonomically difficult insects, such as the parasitoid wasps and aphids, for which many species have yet to be identified from Ireland.

Determining whether an insect species is established as a resident breeding species is not a simple matter. For example, while 32 species of the Odonata (dragonflies and damselflies) have been recorded in Ireland, only 24 (75\%) of these species are known to have established breeding populations (Nelson and Thompson 2004). Four of the species are nineteenth- or early twentiethcentury vagrants; these could justifiably be viewed as extinct, although there is no evidence they were ever established species. Another four species are modern vagrants, of which two are potential colonising species. So from a total figure of 32 a more detailed assessment of status reveals that the actual established number of species is reduced by $25 \%$. The Odonata are a very small group in terms of species, but if these figures 
Table 1-Number of species in the insect orders in Ireland and the literature sources.

\begin{tabular}{|c|c|c|}
\hline Order & No. of Irish species & Literature source \\
\hline Archaeognatha & 4 & Delany 1954 \\
\hline Coleoptera & 2154 & Anderson et al. 1997; 2005 \\
\hline Dermaptera & 3 & Good 1979; Cawley 1999 \\
\hline Diptera & 3313 & Chandler et al. 2008 \\
\hline Ephemeroptera & 33 & Ashe et al. 1998; 2005; Kelly-Quinn and Bracken 2000 \\
\hline Hemiptera & 770 & $\begin{array}{l}\text { Halbert 1935; Hodkinson and White 1979; Carter et al. 1987; De Courcy } \\
\text { Williams 1989; Kirby 1991; Roth and O'Connor 1993; Aukema and } \\
\text { Rieger 1995; 1996; 1999; 2001; 2006; Nelson 1995; Hopkins 2000; } \\
\text { Martin et al. 2000; Helden 2005a; 2005b; 2005c; 2005d; 2005e; 2006a; } \\
\text { 2006b; 2007a; 2007b; 2007c; Aukema et al. 2007; Cuppen and Nelson } \\
\text { 2007; Ben-Dov et al. 2008; Nelson, B. pers. comm. }\end{array}$ \\
\hline Hymenoptera & 3194 & O’Connor et al. 2009 \\
\hline Lepidoptera & 1454 & Bond et al. 2006; 2008 \\
\hline Mecoptera & 1 & King and Halbert 1910 \\
\hline Megaloptera & 2 & Ashe et al. 1998 \\
\hline Neuroptera & 32 & Barnard et al. 1991; O'Connor 2003b \\
\hline Odonata & 34 & Ashe et al. 2005 \\
\hline Orthoptera & 12 & Marshall and Haes 1988; Cawley 2005 \\
\hline Phthiraptera & 117 & $\begin{array}{l}\text { Butler and O'Connor 1994; Doyle et al. 2004; O'Connor 2005; } \\
\text { O'Connor et al. } 2005\end{array}$ \\
\hline Plecoptera & 20 & Ashe et al. 1998 \\
\hline Psocoptera & 46 & Smithers et al. 2000 \\
\hline Siphonaptera & 40 & $\begin{array}{l}\text { Smiddy and Sleeman 1993; Sleeman and Smiddy 1994; Sleeman et al. } \\
1996\end{array}$ \\
\hline Strepsiptera & 4 & $\begin{array}{l}\text { Ronayne and O'Connor 2006a; 2006b; O'Connor and Ronayne } \\
2007\end{array}$ \\
\hline Thysanoptera & 40 & O’Connor 2008 \\
\hline Thysanura & 2 & Delany 1954 \\
\hline Trichoptera & 147 & Ashe et al. 2005 \\
\hline Total & 11,422 & \\
\hline
\end{tabular}

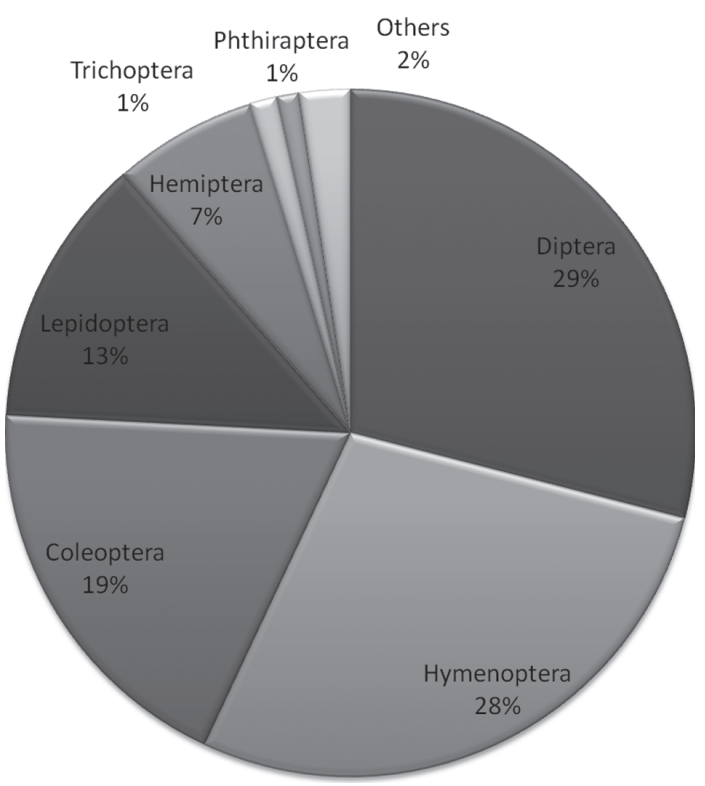

Fig. 1-Ireland's insect fauna by order. were typical the figure of actual biodiversity in Ireland would be much lower than documented here. It is possible to determine if this issue is significant in only a small number of the insect orders present in Ireland because there is a dearth of information on most species. Nevertheless the percentage in the Odonata is extreme, related to the biology and interest in the group. Similarly in the Lepidoptera there are a high proportion of vagrant, non-established species on the checklist, as these species are actively recorded by naturalists (Bond et al. 2006).

The island of Ireland is naturally expected to have fewer species than are found in Great Britain due to the smaller land area, greater isolation and earlier separation from the continental land mass after the last ice age (MacArthur and Wilson 1967). The Irish fauna is essentially a subset of the British one, with less than 100 species confined to the smaller island (Nelson, unpublished data). It has long been known that 
Table 2-A comparison of Ireland's insect diversity with the British and world fauna. Data for British and world species numbers from Natural History Museum (2009).

\begin{tabular}{lcccc}
\hline \multicolumn{1}{c}{ Order } & $\begin{array}{c}\text { No. of world species } \\
\text { described }\end{array}$ & $\begin{array}{c}\text { No. of British } \\
\text { species }\end{array}$ & $\begin{array}{c}\text { No. of Irish } \\
\text { species }\end{array}$ & $\begin{array}{c}\% \text { British } \\
\text { species }\end{array}$ \\
\hline Coleoptera & 350,000 & 4000 & 2154 & $54 \%$ \\
Lepidoptera & 165,000 & 2600 & 1454 & $56 \%$ \\
Diptera & 150,000 & 6800 & 3313 & $49 \%$ \\
Hymenoptera & 150,000 & 7000 & 3194 & $46 \%$ \\
Hemiptera & 84,000 & 1700 & 770 & $45 \%$ \\
Orthoptera & 22,000 & 33 & 12 & $36 \%$ \\
Trichoptera & 10,000 & 198 & 147 & $74 \%$ \\
Odonata & 6000 & 61 & 34 & $56 \%$ \\
Thysanoptera & 5100 & 160 & 40 & $25 \%$ \\
Neuroptera & 4700 & 56 & 32 & $48 \%$ \\
Phthiraptera & 3500 & 97 & 117 & $21 \%$ \\
Psocoptera & 3000 & 51 & 46 & $47 \%$ \\
Ephemeroptera & 2100 & 36 & 33 & $65 \%$ \\
Plecoptera & 2000 & 62 & 20 & $56 \%$ \\
Siphonaptera & 2000 & 7 & 40 & $65 \%$ \\
Dermaptera & 1840 & 10 & 3 & $43 \%$ \\
Strepsiptera & 530 & 4 & 4 & $40 \%$ \\
Mecoptera & 500 & 2 & 2 & $25 \%$ \\
Thysanura & 370 & 7 & 4 & $57 \%$ \\
Archaeognatha & 350 & 3 & 2 & $67 \%$ \\
Megaloptera & 300 & 23,442 & 11,422 & $49 \%$ \\
Total & 963,290 & & & \\
\hline
\end{tabular}

the Irish fauna is less species rich than in Britain. Beirne (1952) measured the ratio as between $55 \%$ and $60 \%$ representation in Ireland of the British and Irish species. However he also noted that the representation in the aquatic groups is much higher than in thermophilic and phytophagous groups. The Irish list comprises, on average, $49 \%$ of the insect species reported from Britain (Table 2). Some orders have a higher proportion recorded, such as the Trichoptera (caddis-flies), with $74 \%$ of the British species, and the Siphonaptera (fleas), with 65\%. The Phthiraptera (lice) have the least proportion recorded $(21 \%)$. Some of the variation will be as a result of climatic differences between the Great Britain and Ireland (such as the low proportion of the thermophilous Orthoptera) and others are probably due to incomplete lists in both Ireland and the Great Britain.

A method for extrapolating from the fraction of species that is known to science to the total species numbers involves the use of species discovery curves. The approach involves plotting a cumulative frequency curve for the taxon with the expectation that this becomes asymptotic when the inventory is reaching completion and new species are becoming more difficult to find.
Bebber et al. (2007) have shown that estimating the number of species using these curves is associated with very large margins of error. However, they are useful to show that the inventory is still not complete. We generated species accumulation curves for two groups of Irish insects, Heteroptera and Chalcidoidea (Hymenoptera) (Fig. 2) to try to establish whether the inventories for these groups in Ireland are complete.

The first records for Irish Heteroptera are from the 1830s. The number of species recorded for Ireland rose above 250 in the 1930s and from then slowly crept up to just under 300 species (the number currently known). The number of species has increased by $15 \%$ in the last 50 years. The accumulation curve appears to have reached an asymptote. The species discovery curve for chalcidoids (Fig. 2) is very different to that of the Heteroptera. Similarly, the first records are from the 1830s, when 119 species were recorded for Ireland (O'Connor et al. 2000). However, over the next 100 years this figure barely rose above 150 species. Recording of chalcidoids was renewed in the 1960s mainly due to M. de Vere Graham (see O'Connor et al. (2000) for references), the number of species almost doubling and continuing to increase steadily up to the 458 

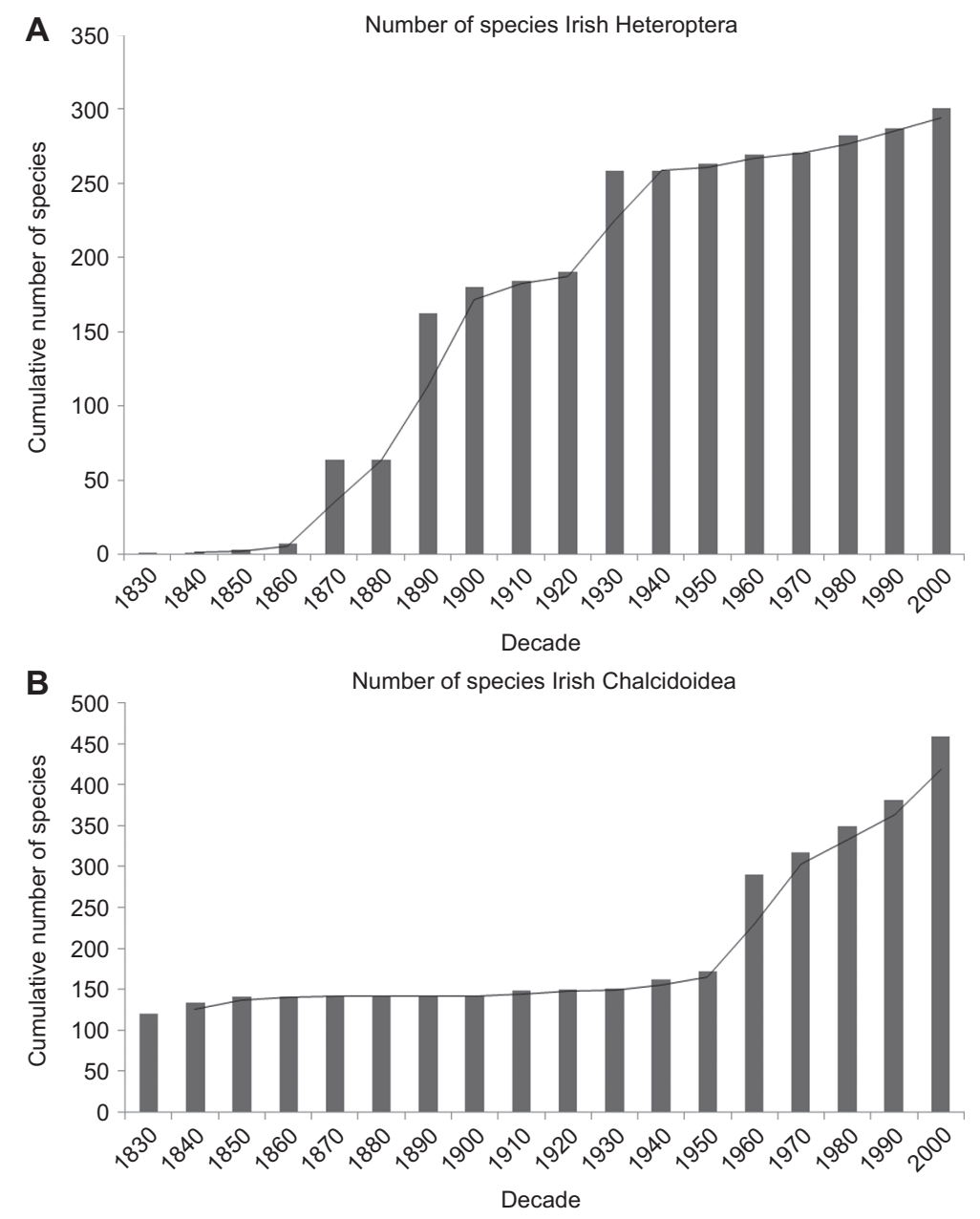

Fig. 2-Cumulative species counts for Irish Heteroptera and Chalcidoid faunas (data from O'Connor et al. 2000 and Brian Nelson, pers. comm.).

species that had been recorded in Ireland by the year 2000 (O’Connor et al. 2000). This species discovery curve does not appear to be reaching an asymptote (the number of species has increased by almost $300 \%$ in the last 50 years), implying that there are more chalcid species to be discovered in Ireland.

These discovery curves show that the figures for Heteroptera are almost complete whereas the inventory for Chalcidoids is not. Good (2009) assumes that $25 \%$ of Irish arthropod species are unrecorded, with species-rich groups such as nematoceran flies and parasitoid wasps likely to have over $50 \%$ of species unrecorded. It is clear, therefore, that the data in Table 1 for the number of insect species in Ireland are underestimates of the true diversity and that there are still more species to be discovered. The number of undiscovered Irish insect species is unknown, but the number is certainly sufficient to increase the total fauna to more than 12,000 species.

\section{EXTINCTION}

If the 2010 commitment is to be met, there must be an assessment that the loss of species has been stopped. However, there is little evidence for the modern extinction from Ireland of many species of insect. The IUCN define extinction as species not recorded after exhaustive survey and within a time-frame appropriate for that species. In Ireland, where there are few insect specialists, it would be hard even to provide convincing evidence of extinction of any insect taxa. Some recent examples demonstrate that a long absence of records does not mean the species is extinct here. The most recent example is the White Prominent moth Leucodonta bicoloria, which was rediscovered in Kerry after more than 70 years (Allen et al. 2008). Others examples include the hoverflies Brachypalpus laphriformis (Speight $1980 ; 1985 ; 2008)$ and Doros profuges (Speight 2008). 
Among the 183 species of Irish hoverfly only four species are considered extinct-Chrysotoxum cautum, Didea alneti, Eristalis cryptarum and Melangyna compositarum (Speight 2008). No Irish butterfly appears to have been lost since the early twentieth century. Among the water beetles, eight species are considered to be extinct in Ireland, having not been seen after 1930 (Foster et al. 2009). This rosy picture of modern extinction from Ireland may be misleading and needs to be assessed in the light of any decline in the distribution of rare Irish species.

\section{ASSESSING BIODIVERSITY LOSS FOR 2010}

Simply counting the published species names is uninformative with regard to the status of the species. We have shown that the known number of insect species for Ireland is certainly less than the actual number, and with such small, often inconspicuous and speciose animals it is difficult to assess species loss and extinction. It is clear that biodiversity indicators need to be developed in order to assess species loss in this country.

The IUCN Red List is widely recognised as the most authoritative and impartial method for classifying species by their risk of extinction. Regional Red Lists for Ireland have been published for bees (Fitzpatrick et al. 2006) and water beetles (Foster et al. 2009). They have shown that one third of the Irish bee fauna and one quarter of the water beetle fauna are under threat of extinction. These two Red Lists account for only 349 species, i.e. only 3\% of the insect fauna has been evaluated for threat of extinction. There is clearly a need for further Red Lists to be developed for Ireland. Using general threat categories, Speight (2008) recognises 50 out of a total of 183 (27\%) Irish syrphid species as being threatened in Ireland. If the two Red Lists and Speight (2008) are representative of the extinction threat to the entire Irish insect fauna, then between 3000 and 4000 Irish insects are potentially under threat of extinction.

The next step would be to use the Red Lists as biodiversity indicators. One of the most welldeveloped direct measures of biodiversity is the IUCN Red List Index (Butchart et al. 2005), but these indexes can only be calculated for a set of species that has been fully assessed twice. Ireland, therefore, not only needs to develop the series of regional Red Lists to include other insect groups but also to repeat these assessments at regular intervals so that biodiversity loss can be assessed. However, this will require the development of Irish insect taxonomic expertise and continued improvement in our knowledge of insect diversity and distribution.

\section{CONCLUSION}

Insects are the most diverse groups of animals in Ireland and therefore make up a huge proportion of our biodiversity. They are fundamentally essential to ecosystem functioning (La Salle and Gould 1993; Weisser and Siemann 2004) and are of enormous economic importance (Hill 1996; Mound 1989 inter alia). Yet despite this, the vast majority of insects are poorly understood and the Irish species list is far from complete. In order to achieve our targets for 2010 under the Convention on Biological Diversity, we need to urgently develop taxonomic expertise, improve our knowledge of insect diversity and distribution and develop a series of regional Red Lists to assess the changes that are occurring in these groups. We are potentially facing an undocumented extinction of 4000 Irish species, whose role in ecosystem functioning we do not understand.

\section{ACKNOWLEDGEMENTS}

We would like to gratefully acknowledge the generous help of Stuart Ball, Ken Bond, Peter Chandler and Alvin Helden. We are grateful to all those field biologists and taxonomists that have collected and published records for Irish fauna, which formed the basis of this paper. The authors Eugenie Regan and Stephen McCormack would also like to thank Lily Kate and Oisín McCormack for support.

\section{REFERENCES}

Allen, D., Mellon, C., Hughes, M., Telfer, M. and Waring, P. 2008 The rediscovery of the White Prominent Leucodonta bicoloria (D.\& S.) in Ireland in 2008. Atropos 35, 3-8.

Anderson, R., Nash, R. and O'Connor, J.P. 1997 Irish Coleoptera. A revised and annotated list. Irish Naturalists' Journal Special Entomological Supplement.

Anderson, R., Nash, R. and O'Connor, J.P. 2005 Checklist of Irish Coleoptera. InvertebrateIreland Online, Ulster Museum, Belfast and National Museum of Ireland, Dublin.

Ashe, P., O'Connor, J.P. and Murray, D.A. 1998 A checklist of Irish aquatic insects. Occasional Publication of the Irish Biogeographical Society no. 3. Dublin. Irish Biogeographical Society. 
Ashe, P., O'Connor, J.P. and Murray, D.A. 2005 A checklist of Irish Aquatic Insects. Belfast and Dublin. InvertebrateIreland Online, Ulster Museum and National Museum of Ireland.

Aukema, B. and Rieger, C. (eds) 1995 Catalogue of the Heteroptera of the Palaearctic Region, Volume 1: Introduction, Enicocephalomorpha, Dipsocoromorpha, Nepomorpha, Gerromorpha and Leptopodomorpha. Amsterdam. Netherlands Entomological Society.

Aukema, B. and Rieger, C. (eds) 1996 Catalogue of the Heteroptera of the Palaeartic Region, Volume 2: Nabidae, Microphysidae, Anthocoridae and Cimicidae, Tingidae, Joppeicidae and Reduviidae, Pachynomidae. Amsterdam. Netherlands Entomological Society.

Aukema, B. and Rieger, C. (eds) 1999 Catalogue of the Heteroptera of the Palaeartic Region, Volume 3: Miridae. Amsterdam. Netherlands Entomological Society.

Aukema, B. and Rieger, C. (eds) 2001 Catalogue of the Heteroptera of the Palaeartic Region, Volume 4: Pentatomomorpha includes families Aradidae, Lygaeidae, Piesmatidae, Malcidae, Berytidae, Colobathristidae, Largidae, Pyrrhocoridae. Amsterdam. Netherlands Entomological Society.

Aukema, B. and Rieger, C. (eds) 2006 Catalogue of the Heteroptera of the Palaeartic Region, Volume 5: Pentatomomorpha II. Amsterdam. Netherlands Entomological Society.

Aukema, B., Hermes, D.J., Nelson, B. and O'Connor, J.P. 2007 Eleven land and water bugs new to the Irish list (Insecta: Heteroptera). Irish Naturalists' Journal 28, 327-33.

Baillie, J.E.M., Hilton-Taylor, C. and Stuart, S.N. (eds) 2004 A global species assessment. Geneva. IUCN.

Barnard, P.C., O'Connor, J.P. and Speight, M.C.D. 1991 A review of the published distribution data for Irish Neuroptera (Insecta), together with additional records and a checklist of the Irish species. Bulletin of the Irish Biogeographical Society 14, 109-23.

Bebber, D.P., Marriott, F.H.C., Gaston, K.J., Harris, S.A. and Scotland, R.W. 2007 Predicting unknown species numbers using discovery curves. Proceedings of the Royal Society B: Biological Sciences 274 (1618), 1651-8.

Beirne, B.P. 1952 The origin and history of the British fauna. London. Methuen.

Beirne, B.P. 1985 Irish Entomology: the first hundred years. Irish Naturalists' Journal Special Entomological Supplement.

Ben-Dov, Y., Miller, D.R. and Gibson, G.A.P. 2008 Scalenet, scales in a country query results. www.sel.barc. usda.gov/scalenet/scalenet.htm. Accessed 30 August 2010.

Bond, K.G.M., Nash, R. and O'Connor, J.P. 2006 An annotated checklist of Irish butterflies and moths (Lepidoptera). Dublin. Irish Biogeographical Society and National Museum of Ireland.

Bond, K.G.M., Nash, R. and O'Connor, J.P. 2008 An annotated checklist of Irish butterflies and moths (Lepidoptera). Belfast and Dublin.
InvertebrateIreland Online, Ulster Museum and National Museum of Ireland.

Butchart, S.H.M., Stattersfield, A.J., Baillie, J., Bennun, L.A., Stuart, S.N., Akçakaya, H.R., Hilton-Taylor, C. and Mace, G.M. 2005 Using Red List Indices to measure progress towards the 2010 target and beyond. Philosophical Transactions of the Royal Society B 360, 255-68.

Butler, F.T. and O'Connor, J.P. 1994 A review of Irish Ischnocera and Amblycera (Phthiraptera). Irish Naturalists' Journal 24, 449-57.

Carter, C.I., Wood-Baker, C.S. and Polaszek, A. 1987 Species, host plants and distribution of aphids occurring in Ireland. Irish Naturalists' Journal 22, 266-84.

Cawley, M. 1999 Forficula lesnei Finot 1887, an earwig (Dermaptera: Forficulidae) new to Ireland. Irish Naturalists' Journal 26, 272-3.

Cawley, M. 2005 Notes and records on some Irish Orthoptera and Dermaptera. Bulletin of the Irish Biogeographical Society 29, 300-7.

Chandler, P.J., O'Connor, J.P. and Nash, R. 2008 An annotated checklist of the Irish two-winged flies (Diptera). Dublin. Irish Biogeographical Society and National Museum of Ireland.

Cuppen, J.G.M. and Nelson, B. 2007 Microneta griscola Horváth, a new water boatman for Ireland (Heteroptera: Corixidae). Irish Naturalists' Journal 28, 410-1.

DAHGI 2002 National Biodiversity Plan. Dublin. Department of Arts, Heritage, Gaeltacht and the Islands.

Delany, M.J. 1954 Thysanura and Diplura. Handbooks for the identification of British insects 1 (2), 1-7.

De Courcy Williams, M. 1989 A preliminary list of the Irish Auchenorrhyncha (Homoptera). Bulletin of the Irish Biogeographical Society 12, 135-48.

Doyle, Ú., O’Halloran, J. and Smiddy, P. 2004 Records of the feather lice (Mallophaga) Philopterus cincli Denny and Myrsidea franciscoloi Conci, two species new to Ireland. Irish Naturalists' Journal 27, 440.

EPA 2008 Ireland's Environment 2008. Wexford. Environmental Protection Agency.

European Commission 2006 Communication from the Commission. Halting the Loss of Biodiversity by 2010 - and Beyond. COM(2006) 216 final. European Commission, Brussels.

Ferriss, S.E., Smith, K.G. and Inskipp, T.P. (eds) 2008 Irish Biodiversity: a taxonomic inventory of fauna. Irish Wildlife Manuals no. 38. Dublin. National Parks and Wildlife Service, Department of Environment, Heritage and Local Government.

Finlay, B.J., Thomas, J.A., McGavin, G.C., Fenchel, T. and Clarke, R.T. 2006 Self-similar patterns of nature: insect diversity at local to global scales. Proceedings of the Royal Society 273, 1935-41.

Foster, G.N., Nelson, B.H. and O Connor, Á. 2009 Ireland Red List No. 1-Water beetles. Dublin. 


\section{Biology AND ENVIRONMENT}

National Parks and Wildlife Service, Department of Environment, Heritage and Local Government, Ireland.

Good, J.A. 1979 The lesser earwig Labia minor L. (Dermaptera: Labiidae) in Ireland. Irish Naturalists' Journal 19, 448.

Good, J.A. 2009 Local and regional studies of crytobiota: esoteric stamp collecting or essential ecology? Bulletin of the Irish Biogeographical Society 33, 133-69.

Gullan, P.J. and Cranston, P. 2004 The insects: an outline of entomology. UK. Wiley-Blackwell.

Halbert, J.N. 1935 A list of the Irish Hemiptera (Heteroptera and Cicadina). Proceedings of the Royal Irish Academy 42B, 211-318.

Helden, A. 2005a A first Irish record of the typhlocybine leafhopper Edwardsiana prunicola (Edwards, 1914). Entomologist's Monthly Magazine 141, 186.

Helden, A. 2005b Aphrodes aestuarina (Edwards), a leafhopper new to Ireland, with some notes on its status and identification. Entomologist's Monthly Magazine 141, 161-2.

Helden, A. 2005c The typhlocybine (Hem. - Hom.) leafhopper Alebra wahlbergi (Boheman, 1845), new to Ireland. Entomologist's Monthly Magazine 141, 214.

Helden, A. 2005d Interesting Auchenorrhyncha records from sand dunes in north Co. Dublin, including a new species for Ireland: Anaceratagallia (Agallia) ribauti (Ossiannilsson, 1938). Irish Naturalists' Journal 28, 173-4.

Helden, A. 2005e Kybos virgator (Ribaut, 1933) (Cicadellidae, Typhlocybinae) new to Ireland, and a second known Irish population of the leafhopper Ossiannilssonola callosa (Then, 1886). Irish Naturalists' Journal 28, 174-5.

Helden, A. 2006a Kybos populi (Edwards, 1908) (Hemiptera: Cicadellidae) an aspen feeding leafhopper new to Ireland. Irish Naturalists' Journal 28, $341-2$.

Helden, A. 2006b Wagneripteryx (Aguriahana) germari (Zetterstedt), a species of typhlocybine leafhopper (Hem.) new to Ireland. Entomologist's Monthly Magazine 142, 184.

Helden, A. 2007a Discovery of the second European species of Megophthalmus Curtis (Hemiptera, Cicadellidae, Megophthalminae) in Ireland. Irish Naturalists' Journal 28, 418.

Helden, A. 2007b Xanthodelphax straminea (Stål, 1858) (Hemiptera: Delphacidae) new to Ireland. Entomologist's Monthly Magazine 143, 130.

Helden, A. 2007c Three species of Edwardsiana Zakhvatkin (Hemiptera: Cicadellidae: Typhlocybinae) new to Ireland. Entomologist's Monthly Magazine 143, 129.

Hodkinson, I.D. and White, I.M. 1979 Homoptera: Psylloidea. Handbooks for the identification of British Insects 2 (5a), 1-98.
Hopkins, G.W. 2000 Additions to the Irish aphid list. Irish Naturalists' Journal 26, 175-6.

Kelly-Quinn, M. and Bracken, J.J. 2000 The distribution of the Ephemeroptera in Ireland. Occasional Publication of the Irish Biogeographical Society no. 5.

King, J.J.F.X. and Halbert, J.N. 1910 A list of the Neuroptera of Ireland. Proceedings of the Royal Irish Academy 28B, 29-112.

Kirby, P. 1991 Hemiptera (Heteroptera and Auchenorrhyncha) recorded from south-west Ireland, Cos Cork, Kerry and Clare, September 1989. Bulletin of the Irish Biogeographical Society 14, 90-104.

La Salle, J. and Gould, I.D. (eds) 1993 Hymenoptera and biodiversity. Washington D.C. CAB, International.

MacArthur, R.H. and Wilson, E.O. 1967 The theory of island biogeography. Princeton. Princeton University Press.

Marshall, J.A. and Haes, E.C.M. 1988 Grasshoppers and allied insects of Great Britain and Ireland. Colchester. Harley Books.

Martin, J.H., Mifsud, D. and Rapisarda, C. 2000 The whiteflies (Hemiptera: Aleyrodidae) of Europe and the Mediterranean Basin. Bulletin of Entomological Research 90, 407-48.

May, R.M. 1990 How many species? Philosophical Transactions of the Royal Society of London 330, 293-304.

McCarthy, T.K. 1986 Biogeographical aspects of Ireland's invertebrate fauna. In D.P. Sleeman, R.J. Devoy and P.C. Woodman (eds), Proceedings of the Postglacial Colonization Conference, 67-81. Occasional Publication of the Irish Biogeographical Society no. 1. Dublin. Irish Biogeographical Association.

Mound, L. (ed.) 1989 Common insect pests of stored food products. London. British Museum (Natural History).

Nash, R. 1983 A brief summary of the development of entomology in Ireland during the years 17901870. Irish Naturalists' Journal 21, 145-50.

Natural History Museum 2009 NBN Species Dictionary, Arthropoda [online]. Available at http://nbn.nhm.ac.uk/nhm/arthrop.shtml [accessed 28 May 2009].

Nelson, B. 1995 The distribution of the aquatic and semi-aquatic Heteroptera in Northern Ireland. Bulletin of the Irish Biogeographical Society 18, 66-130.

Nelson, B. and Thompson, R. 2004 The natural history of Ireland's dragonflies. MAGNI publication no. 013. Belfast. National Museums and Galleries of Northern Ireland Belfast.

O'Connor, J.P. 1997 Insects and entomology. In J.W. Foster (ed.), 219-40. Nature in Ireland. Dublin. Lilliput Press.

O'Connor, J.P. 2003 Wax flies (Neuroptera: Coniopterygidae) reared from cola nut and marble 
galls, including Coniopteryx borealis Tjeder new to Ireland. Entomologist's Gazette 54, 207-9.

O’Connor, J.P. 2005 Ricinus fringillae DeGeer (Mallophaga: Amblycera) new to Ireland. Irish Naturalists' Journal 28, 172.

O'Connor, J.P. 2008 A review of Irish thrips (Thysanoptera). Irish Naturalists' Journal 29, $20-4$.

O'Connor, J.P., Sleeman, D.P. and Butler, F.T. 2005 A review of the Irish Anoplura (Insecta: Phthiraptera). Irish Naturalists' Journal 28, 62-7.

O'Connor, J.P. and Ronayne, C. 2007 Stylops melittae Kirby (Strepsipt, Stylopidae) new to Ireland. Entomologist's Monthly Magazine 143, 199.

O'Connor, J.P., Nash, R. and Boucek, Z. 2000 A catalogue of the Irish Chalcidoidea. Bulletin of the Irish Biogeographical Society and National Museum of Ireland.

O'Connor, J.P., Nash, R. and Broad, G. 2009 An annotated checklist of the Irish Hymenoptera. Dublin. Irish Biogeographical Society and National Museum of Ireland.

Purcell, P. 1996 Biodiversity in Ireland: an inventory of biological diversity on a taxonomic basis. Fauna. Unpublished report to the Heritage Policy Unit, Department of the Arts, Culture and the Gaeltacht.

Regan, E. and McCormack, S. 2009 Class Insecta. In S.E. Ferriss, K.G. Smith and T.P. Inskipp (eds.), 97-111. Irish Biodiversity: a taxonomic inventory of fauna. Irish Wildlife Manuals no. 38. Dublin. National Parks and Wildlife Service, Department of Environment, Heritage and Local Government.

Ronayne, C. and O'Connor, J.P. 2006 Halictoxenos tumulorum Perkins and $H$. spencei Nassonov (Strepsipt. Stylopidae) new to Ireland. Entomologist's Monthly Magazine 142, 92.
Roth, S. and O'Connor, J.P. 1993 A review of the Irish Nabinae (Insecta: Hemiptera, Nabidae). Bulletin of the Irish Biogeographical Society 16, 9-17.

Sleeman, D.P. and Smiddy, P. 1994 Bat fleas in Ireland: a review. Irish Naturalists' Journal 24, 444-8.

Sleeman, D.P., Smiddy, P. and Moore, P. 1996 The fleas of Irish terrestrial mammals: a review. Irish Naturalists' Journal 25, 237-48.

Smiddy, P. and Sleeman, D.P. 1993 Avian fleas in Ireland: a review of their distribution and hosts. Irish Birds 5, 55-60.

Smithers, C.N., O’Connor, J.P. and Peters, J.V. 2000 A list of Irish Psocoptera (Insecta) (Booklice, Barklice, Psocids). Irish Naturalists' Journal 26, 228-35.

Speight, M.C.D. 1980 Brachypalpus laphriformis (Diptera: Syrphidae) in Ireland and its probable demise. Irish Naturalists' Journal 20, 70-2.

Speight, M.C.D. 1985 Adjustments to the Irish hoverfly list (Diptera: Syrphidae). Irish Naturalists' Journal 21, 385-91.

Speight, M.C.D. 1986 Use of invertebrates, as exemplified by certain insect groups, in considering hypotheses about the history of the Irish postglacial fauna. In D.P. Sleeman, R.J. Devoy and P.C. Woodman (eds), Proceedings of the Postglacial Colonization Conference, 60-66. Occasional Publication of the Irish Biogeographical Society no. 1. Dublin. Irish Biogeographical Society.

Speight, M.C.D. 2008 Database of Irish Syrphidae (Diptera), Irish Wildlife Manuals no. 36. Dublin. Department of Environment, Heritage and Local Government.

United Nations 1992 Convention on Biological Diversity, Article 2. Available: http://www. biodiv.org/convention/articles.asp [accessed 8 December 2009].

Weisser, W.W. and Siemann, E. (eds) 2004 Insects and ecosystem function. Berlin. Springer. 